\title{
MODERN TREATMENT OF ENDOMETRIAL LOCAL HYPERPLASTIC PROCESSES FROM POSITIONS OF THE PATHOGENIC APPROACH
}

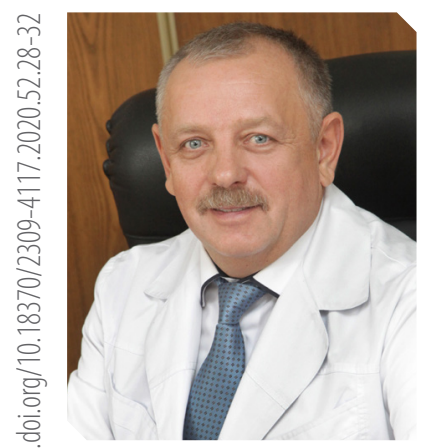

V.0. BENYUK

$M D$, professor, head of the Obstetrics and Gynecology Department No. 3,

Bogomolets National Medical University, Kyiv

ORCID: 0000-0002-5984-3307

Y.V. KRAVCHENKO

graduate student, Obstetrics and

Gynecology Department No. 3,

Bogomolets National Medical

University, Kyiv

ORCID: 0000-0001-6263-3514

T.V. KOVALIUK

PhD, assistant professor, Obstetrics and Gynecology Department №. 3,

Bogomolets National Medical

University, Kyiv

ORCID: 0000-0001-9339-881X

\section{S.V. BENIUK}

PhD, assistant professor, Obstetrics and Gynecology Department №. 3, Bogomolets National Medical

University, Kyiv

ORCID: 0000-0003-4273-3934

\section{I.A. USEVYCH}

PhD, assistant professor, Obstetrics

and Gynecology Department No.

3, Bogomolets National Medical

University, Kyiv

ORCID: 0000-0001-5200-8184

\section{Contacts:}

Tetiana V. Kovaliuk

Bogomolets National Medical

University, Obstetrics and Gynecology

Department No. 3, Kyiv City

Maternity Hospital №. 3

V. Kuchera str. 7

03148, Kyiv, Ukraine

Tel.: +38 (066) 4224721

email: tatyanah7@meta.ua

\section{INTRODUCTION}

Unfavorable ecology, demographic situation in Ukraine, somatic and oncologic diseases frequency increase, immunity and living standard decrease have predetermined the increase of number of women with endometrial hyperproliferative processes who stand for $5-20 \%$ obstetric-gynecologic profile, according to the statistical data $[2,6,14,16,19]$.

Nowadays regardless of the scientific achievements, diagnostics, surgery and curative methods improvement, the problem of intrauterine pathology treatment still remains topical in the medical and social aspects which is determined by the high risks of neoplastic transformation and steady tendency towards the recurrence frequency increase (proportional transformation into atypia), which according to the homeland and foreign authors stands for 26 to $78 \%$ among women [1, 3, 15, 17-19, 22]. High recurrence frequency serves the ground for the repeated surgical operations $[10,12,18,21,23]$, and sometimes they are not limited with traditional approaches possibilities, that is increases the topicality study of the main aspects of disease.

Relevance of the problem is determined by the probability of the endometrial hyperplastic processes transformation into the endometrial cancer. Numerous researches prove the probability of the oncological processes development with the background of endometrial polyposis from $4 \%$ up to $67.2 \%$ of patients $[13,24,25]$. The endometrium polyposis treatment methods are standard ones and foresee the polyp's ablation followed by the hormonal therapy, nevertheless the recurrence value remains rather high standing for $25.9 \%$ to $78 \%[4,5,11]$.

The disease's etiopathogenesis complexity, different trends in its stages' interpretation, tactical approaches ambiguity (with and without considering the hormonal disorder individual specific features) constitute definite difficulties while choosing the pathogenetically treatment. These are the circumstances to determine the increased scientific and practical interest in the endometrial polyposis treatment and management $[7,8,9,22]$.

The topicality of our research has been determined by the controversial point of view on the uterus polyps pathogenesis, high recurrence frequency after hormonal therapy, immune system dysfunction and inflammation role in the endometrial polyposis genesis.

The purpose of research: to increase the treatment effectiveness of patients with endometrium local hyperplasia (endometrium polyposis) by applying of the new endoscopic technologies and pathogenetically substantiated post-surgery therapy.

\section{MATERIALS AND METHODS}

66 women aged $24-43$ years participated in the research. The treatment algorithm consisted of four stages in accordance with Order of the Ministry of Health or Ukraine No. 676 dated by 31.12.2004.

Stage I - hysteroscopic mutated endometrial and polyp ablation followed by the morphological research and the following determination of tactics depending on the pathology type along with the complex anti-inflammatory, anti-bacterial and anti-viral treatment.

Stage II - hormonal therapy aimed at the endometrial suppression.

Stage III - hormonal status optimization for the hyperestrogenemia prevention.

Stage IV - dispensary observation within 6 months after surgery and within 5 years after hormonal therapy.

The nature of the endometrial pathological process was determined after general clinical examination by diagnostic hysteroscopy with the following pathohistological verification of the diagnosis and the immunohistochemical profile of endometrial establishing (Fig.).

After the comprehensive examination conducted and histological verification of the diagnosis, patients with endometrial polyposis were divided into 2 groups: $A(n=34)$ and $B(n=32)$. Taking into account the revealed new pathogenetic stages of the endometrial polyposis development in patients of group A their treatment was supplemented by immunomodulatory therapy with the interferon inducer (cycloferon according to the scheme).

Examination and treatment were performed according to the protocol of the Ministry of Health of Ukraine, but algorithm of examination was additionally supplemented by the immune histochemical study of the endometrium with determination of its immune histochemical profile, which allows to determining the receptor 


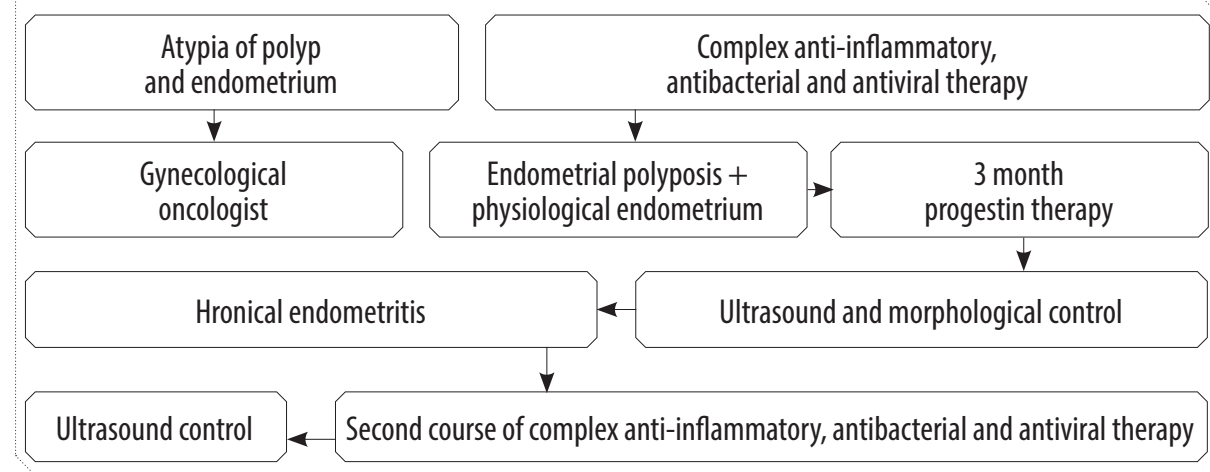

Figure. Treatment algorithm for women with endometrial polyposis

phenotype, presence of inflammatory process, and investigating the apoptosis state and intra-intestinal system therapy. Immune histochemical studies were performed at the Pathomorphology Department of Clinical Hospital "Feofania".

The DAKO LSAB + kit (Dako corporation USA) universal peroxidase method was used to define the immune histochemical reaction. In order to study the cytokines content, lavage from the uterine cavity was obtained immediately before hysteroscopy by scraping the walls of the uterine cavity with injecting 3-4 $\mathrm{ml}$ of warmed saline through the onetime-use pediatric Foley catheter. The Foley catheter was inserted into the uterine cavity without previous expansion of the cervical canal prior to instrumental scraping. The fluid was obtained by attaching a single $5 \mathrm{ml}$ syringe to the catheter. The fluid injected was aspirated after 20-30 seconds. The lavage was frozen and stored until the study at $15-18{ }^{\circ} \mathrm{C}$. Material was thawed and centrifuged for 15 minutes at $1500 \mathrm{~g}$ before the study. Biochemical studies were performed in the liquid above the precipitate. The results were recalculated to $1 \mathrm{mg}$ of intrauterine lavage protein, which allows the standardization of the data obtained. Protein in all lavages was determined by means of the Lowry method.

The sets for the tumor necrosis factor- $a$ (TNF- $a$ ) cytokines for their hard phase detection by the "Vector-Brest" ELISA method were used to define the TNF-a cytokines value.

The microbiological studies were performed on the basis of the clinical laboratory in Clinical Hospital "Feofania" and LLC "Institute of Microbiological Research", medical laboratory "Dila" with polymerase chain reactions, aerobic and anaerobic technologies. The microbio- logical researches were performed according to Order No. 4 of the Ministry of Health of Ukraine (1996) and Order No. 59 of the Ministry of Health of Ukraine from 10.02.2003. The resulting material was inoculated on a set of standard media (liquid and helium) and cultured under aerobic, anaerobic and reduced oxygen content conditions.

After operative stage of treatment (hysteroscopy with polypectomy) patients were prescribed antibacterial therapy according to the standard scheme (fluoroquinolones in combination with metronidazole).

Both groups according to the protocol received hormone therapy with dydrogesterone $20 \mathrm{mg}$ per day within the range of 5 to 25 days. The control of the endometrial status was performed in 3 and 6 months, considering the features of chronic endometritis, evaluating clinical data, the nature of menstruation and its cyclicity.

\section{STUDY RESULTS AND DISCUSSION}

Active histological screening of the endometrial status showed that 9 (26.5\%) patients in group A had features of chronic endometritis (positive reaction of CD-138 and CD-68 markers) in 3 months after complex treatment, which determined a repeated course of treatment with viral and bacteriological examination data taken into account. Chronic endometritis was diagnosed in $15(46.9 \%)$ in group B, which is $20.4 \%$ more than in group $A$ (Table 1 ).

The features of the treatment effect on the state of receptor phenotype have been established among women who received progestins. Administration of progestins resulted in a decrease in the progesterone receptors level in the epithelium of glands in 1.4 times, that has compensatory nature in our opinion (Tables 2, 3).

It should be noted separately from the results of the CD 138 analysis. In our opinion there is a number of patients with a positive value but not the average level of this marker in the group. This immune histochemical criterion is good for normal and increases with the development of chronic endometritis, be-

Table 1. Presence of chronic endometritis with the physiological endometrium background after 3 months of treatment

\begin{tabular}{|c|c|}
\hline Group A $(n=34)$ & Effectiveness, $n(\%)$ \\
\hline Absence of immunohistochemical features of chronic endometritis & $25(73.5)$ \\
\hline Presence of immunohistochemical features of endometritis & $9(26.5)$ \\
\hline Group B $(n=32)$ & Effectiveness, $n(\%)$ \\
\hline Absence of immunohistochemical features of endometritis & $17(53.1)$ \\
\hline Presence of immunohistochemical features of endometritis & $15(46.9)$ \\
\hline
\end{tabular}

Table 2. Specific features of endometrium immune histochemical profile in group A during treatment

Immunohistochemical profile of endometrium

Progesterone receptors in epithelium (in HISTOScore points)

Estrogen receptors in epithelium (in HISTOScore points)

Endothelial cells in field of view

B-cell lymphoma 2 protein (points)

CD 138 expression (\%)

CD 68 expression (\%)
Group A

Before treatment After treatment

\begin{tabular}{|c|c|}
\hline $218.1 \pm 7.6$ & $154.1 \pm 6.7^{*}$ \\
\hline $202.3 \pm 9.5$ & $168.8 \pm 12.7$ \\
\hline $4.1 \pm 0.08^{*}$ & $3.6 \pm 0.09$ \\
\hline $1.8 \pm 0.06^{*}$ & $1.2 \pm 0.04$ \\
\hline $15.2 \pm 1.5^{*}$ & $6.9 \pm 1.5$ \\
\hline $34(100 \%)$ patients & $\ln 9(26.5 \%)$ patients \\
\hline $12.7 \pm 3.1^{*}$ & $5.8 \pm 1.3$ \\
\hline
\end{tabular}

* variation is valid between indicators before and after treatment 
Table 3. Specific features of endometrium immune histochemical profile in group B during treatment

Immunohistochemical profile of endometrium

Progesterone receptors in epithelium (in HISTOScore points)

Estrogen receptors in epithelium (in HISTOScore points)

Endothelial cells in field of view

B-cell lymphoma 2 (points)

CD 138 expression (\%)

CD 68 expression (\%)

* variation is valid between indicators before and after treatment

cause as it was shown by our studies the "classical" pathomorphological features of chronic endometritis may not be fully represented.

Complex virus-bacterial screening showed a sharp decrease in the number of pathogenic contamination of the endometrium against the background of the growth of virus-bacterial associations. Bacterial screening showed the presence of anaerobic microflora Prevotella spp., Veilonella spp., Peptostreptococcus spp., Gardnerella vaginalis, emphasizing the need for antibacterial therapy (Table 4, 5).

The study of uterine contamination by polymerase chain reaction detected viral infection - herpes simplex virus type I and II, cytomegalovirus, human papillomavirus.

The presence of Mycoplasma hominis should be emphasized and it stands for $2.9 \%$. Our researches indicate the need to control Mycoplasma hominis contamination in endometrial and to treat patients, although there is widespread debate about the role of Mycoplasma hominis in the genesis of chronic endometritis.

TNF-a value in lavages from the uterine cavity indicated a unidirectional trend with the CD 138 dynamics (Table 6). Decrease in 3 times in group $A$ and in 1.5 times in group $B$ was observed after treatment.

It is important to emphasize that the increase in TNF-a has a direct tendency with the CD 138 level, clearly correlates with its level and can be used as a diagnostic criterion for the inflammatory process in the endometrium.

However, it should be noted that the level of this marker can be increased in hyperproliferative endometrial processtion of the obtained data. es and in endometrial atypia, that is requires differentiated integrative evalua-

The effectiveness of treatment in group $A$ was determined in one year in 29 (85.2\%) patients and in 5 (14.8\%) women experienced a recurrence of lo-

\begin{tabular}{|c|c|}
\hline Before treatment & After treatment \\
\hline $202.1 \pm 9.6$ & $165.1 \pm 8.7^{*}$ \\
\hline $193.3 \pm 9.5$ & $159.8 \pm 8.4$ \\
\hline $3.9 \pm 0.07^{*}$ & $3.6 \pm 0.09$ \\
\hline $1.8 \pm 0.06^{*}$ & $1.6 \pm 0.04$ \\
\hline $14.8 \pm 1.5^{*}$ & $8.2 \pm 1.5$ \\
\hline $\ln 32(100 \%)$ patients & $\ln 15(46.9 \%)$ patients \\
\hline $12.7 \pm 3.1^{*}$ & $5.8 \pm 1.3^{*}$ \\
\hline
\end{tabular}

Table 4. Structure of the endometrial bacterial contamination in months after treatment

\begin{tabular}{|c|c|c|}
\hline Groups & Group $A(n=9)$ & Group B $(n=15)$ \\
\hline Prevotella spp. & 3 & 5 \\
\hline Veilonella spp. & 2 & 4 \\
\hline Peptostreptococcus spp. & 1 & 2 \\
\hline Gardnerella vaginalis. & 2 & 3 \\
\hline
\end{tabular}

Table 5. Viral-bacterial structure of endometrial biopsy specimen in 3 months after treatment

\begin{tabular}{|c|c|c|}
\hline Groups & Group A, n (\%) & Group B, n (\%) \\
\hline Herpes simplex virus type I and II & $3(7.8 \%)$ & $4(7.6 \%)$ \\
\hline $\begin{array}{c}\text { Cytomegalovirus } \\
\text { Human papillomavirus highly } \\
\text { oncogenous }\end{array}$ & $2(2.9 \%)$ & $1(2.6 \%)$ \\
\hline Mycoplasma hominis & $1(7.8 \%)$ & $3(11.5 \%)$ \\
\hline
\end{tabular}

Table 6. Dynamics of TNF-a level in lavages from the uterine cavity, $\mathrm{pg} / \mathrm{ml}$

\begin{tabular}{c|cc}
\hline Groups & & Level dynamics \\
& Before treatment & After treatment \\
\hline Group A & $41.1 \pm 5.3$ & $13.6 \pm 1.7^{*}$ \\
\hline Group B & $\ln 34(100 \%)$ patients & $\ln 9(26.5 \%)$ patients \\
\hline & $39.9 \pm 4.5$ & $26.1 \pm 7.2$ \\
In $32(100 \%)$ patients & $\ln 15(46.9 \%)$ patients
\end{tabular}

* variation is valid between indicators before and after treatment

Table 7. Results of treatment of patients with the endometrial polyposis

\begin{tabular}{|c|c|c|c|}
\hline Groups & Number & Effectiveness, n (\%) & Endometrial polyposis recurrence, $\mathrm{n}(\%)$ \\
\hline $\begin{array}{l}\text { Group A } \\
\text { (endometrium ablation + } \\
\text { hysteroscopy + immune } \\
\text { modulatory therapy) }\end{array}$ & $n=34$ & $29(85.2)$ & $5(14.8)$ \\
\hline $\begin{array}{c}\text { Group B } \\
\text { (endometrium ablation + } \\
\text { hysteroscopy) }\end{array}$ & $n=32$ & $20(62.5)$ & $12(37.5)$ \\
\hline
\end{tabular}


Supplementation of antibacterial treatment with immune corrective therapy promotes the restoration of the receptor phenotype, normalizes the TNF level, increases the effectiveness of treatment of local endometrial hyperplasia (endometrial polyps) by $22.7 \%$. The use of active tactics of immune histochemical and virus-bacterial control over the endometrium in 3 months after surgical treatment allows identifying the category of patients with the recurrent chronic endometritis, conducting timely treatment and improving the results of the local endometrial hyperplasia treatment from $62.5 \%$ to $85.2 \%$, which, in turn, is a prevention of reoccurrence.

\section{REFERENCES/ЛITEPATУPA}

1. Artymuk, N.V., Guljaeva, L.F., Zotova, O.A.

"Features of metabolism and estrogen reception in hyperplastic processes of the endometrium and endometriosis." Mother and Baby in Kuzbass 1 (2012): 8-12.

Артымук, Н.B.

Особенности метаболизма и рецепция эстрогенов при гиперпластических процессах эндометрия и эндометриозе / H.B. Артымук, Л.Ф. Гуляева, О.А. Зотова // Мать и дитя в Кузбассе. 2012. - № 1. - C. 8-12.

2. Benyuk, V.A., Goncharenko, V.N., Zabudskij, A.V., et al. Intrauterine pathology. Kyiv. Zdorov'e Ukrainy (2013): 206 p.

Бенюк, В.А.

Внутриматочная патология / В.А. Бенюк, В.Н. Гончаренко,

А.В. Забудский и др. - К.: «Здоровье Украины», 2013. - 206 с.

3. Benyuk, V.A., Goncharenko, V.M.

"Clinical and morphological justification of the differential algorithm for the treatment of endometrial hyperplastic processes in women of reproductive age." Ohrana materinstva i detstva 1.23 (2014): 17-21. Бенюк, В.А.

Клинико-морфологическое обоснование дифференциального алгоритма лечения гиперпластических процессов эндометрия у женщин репродуктивного возраста / В.А. Бенюк, В.М. Гончаренко // Охрана материнства и детства. - 2014. - № 1 (23). - С. 17-21.

4. Benyuk, V.O., Makarenko, M.V., Dyndar, O.A., et al.

Algorithms in obstetrics and gynecology. Kyiv. Doktor-Media Ltd

(2016): $510 \mathrm{p}$

Бенюк, В.О.

Алгоритми в акушерстві і гінекології / В.О. Бенюк,

М.В. Макаренко, О.А. Диндар та ін. - К.: ТОВ «Доктор-Медіа»,

2016. $-510 \mathrm{C}$.

5. Benyuk, V.0., Usevich, I.A. Nikoniuk, T.R.

"New methods of treatment of endometrial hyperplastic processes."

In: Collection of scientific works Association of Obstetricians-

Gynecologists of Ukraine. Kyiv. Poligraf plus (2012): 32-5.

Бенюк, В.О.

Інноваційні методи лікування гіперпластичних процесів ендометрія / В.О. Бенюк, І.А. Усевич, Т.Р. Никонюк // Збірник наукових праць Асоціації акушерів-гінекологів України. -

К.: «Поліграф плюс», 2012. - C. 32-35.

6. Vdovychenko, Y.P., Goljanovskyj, O.V, Lopushan, I.P.

"Hyperplasia of the endometrium processes: terminology

etiopatogenia, diagnosis, treatment." Zhinoche zdorovja 6.30 (2012): 12-9.

\section{Вдовиченко, Ю.П.}

Гіперпластичні процеси ендометрія: термінологія, етіопатоленез, діагностика, лікування / Ю.П. Вдовиченко, О.В. Голяновський,

І.П. Лопушан // Жіноче здоров'я. - 2012. - № 6 (30). - C. 12-19.

7. Goncharenko, V.M.

Hyperplastic processes of the endometrium. Prognosis, diagnosis, treatment and rehabilitation. Thesis abstract for MD degree. Kyiv.

Bogomolets National Medical University (2017): 39 p.

Гончаренко, В.М.

Гіперпластичні процеси ендометрія. Прогнозування, діагностика, лікування та реабілітація. Автореф. дис. ... д. мед. н. /

В. М. Гончаренко; НМУ ім. О.0. Богомольця. - Київ, 2017. - 39 с.

8. Goncharenko, V.M., Benyuk, V.O., Kalenska, O.V., Strokan, A.M.

"Immunohistochemical study of the interaction of endometrial apoptosis with the state of the APUD system in normal and pathological conditions." Health of woman 1.107 (2016): 63-7. Гончаренко, В.М.

Імуногістохімічне дослідження взаємодії апоптозу ендометрія зі станом АПУД-системи в нормі і патології / В.М. Гончаренко,

В.0. Бенюк, О.В. Каленська, А.М. Строкан // Здоровье женщины. -2016. - № 1 (107). - C. 63-67.
9. Goncharenko, V.M., Rosha, L.G., Tibin, Y.V., Kalenska, O.V. Organization and conduct of immunohistochemical studies. Guidelines. Kyiv (2015): 33 p.

Гончаренко, В.M.

Організація та проведення іммуногістохімічних досліджень.

Методичні рекомендації / В.М. Гончаренко, Л.Г. Роша, Ю.В. Тібінь,

О.В. Каленська. - Київ, 2015. - 33 с.

10. Zhuk, S.I.

"Algorithms for assisting with abnormal uterine bleeding." Female doctor 4 (2015): 22-31.

Жук, С.И.

Алгоритмы оказания помощи при аномальных маточных кровотечениях / С.И. Жук // Жіночий лікар. - 2015. - № 4. -

C. 22-31.

11. Tatarchuk, T.F., Kalugina, I.V., Tutchenko, T.N.

"Hyperplastic processes of endometrium: what's new?"Reproductive endocrinology 5.25 (2015): 7-13.

Татарчук, Т.Ф.

Гиперпластические процессы эндометрия: что нового? /

Т.Ф. Татарчук, Л.В. Калугина, Т.Н. Тутченко // Репродуктивная эндокринология. - 2015. - № 5. - С. 7-13.

12. Zaporozhan, V.N., Tatarchuk, T.F., Dubinina, V.G., Kosei, N.V.

"Modern diagnostics and treatment of endometrial hyperplastic

processes." Reproductive endocrinology 1.3 (2012): 5-12. D01:

10.18370/2309-4117.2012.3.5-12

Запорожан, В.Н.

Современная диагностика и лечение гиперпластических процессов эндометрия / В.Н. Запорожан, Т.Ф. Татарчук,

В.Г. Дубинина, Н.В. Косей // Репродуктивная эндокринология. 2012. - № 1 (3). - C. 5-12.

13. Zadonskaja, Y.N., Chernyshova, A.L., Kolomiec, L.A., Bochkareva, N.V.

"Immunohistochemical prognosis criteria for endometrial cancer."

Sibirskij onkologičeskij žurnal 1.37 (2010): 79-84.

Задонская, Ю.Н.

Иммуногистохимические критерии прогноза при раке эндометрия / Ю.Н. Задонская, А.Л. Чернышова, Л.А. Коломиец, Н.В. Бочкарева // Сибирский онкологический журнал. - 2010. №1 (37). - C. 79-84.

14. Lysenko, O.V., Zanko, S.N.

"Endometrial hyperplastic processes in different age periods: study of cytokine status and SFAS-ligand content." Obstetrics and Gynecology 4 (2011): 63-8.

Лысенко, О.В.

Гиперпластические процессы эндометрия в различные возрастные периоды: исследование цитокинового статуса и содержания SFAS-лиганда / O.В. Лысенко, С.Н. Занько // Акушерство и гинекология. - 2011. - № 4. - С. 63-68.

15. Makarov, I.0., Ovsyannikova, T.V., Sheshukova, N.A.

"Oncological aspects of hyperplastic processes in the endometrium."

Rossiyskiy vestnik akushera-ginekologa 1 (2011): 13-6.

Макаров, И.О.

Онкологические аспекты гиперпластических процессов в эндометрии / И.О. Макаров, Т.В. Овсянникова, Н.А. Шешукова // Российский вестник акушера-гинеколога. - 2011. - № 1. C. $13-6$.

16. Parashchuk, Y.S., Kalinovska, O.I., Gryshchenko, M.G., Parashchuk V.Y.

Infertility in marriage: a study guide. Kharkiv. KhNMU (2014): 124 p. Паращук, Ю.С.

Безплідність у шлюбі: навчальний посібник / Ю.С. Паращук,

0.І. Каліновська, М.Г. Грищенко, В.Ю. Паращук. - Харків : ХНМУ,

2014. - $124 \mathrm{C}$

17. Pashov, A.I., Tshaj, B.B., Dyhno, Y.A.

Proliferative processes of the endometrium: pathogenesis, prognosis, early diagnosis. Monograph. Novosibirsk. Nauka (2013): 258 p.
Пашов, А.И.

Пролиферативные процессы эндометрия: патогенез, прогнозирование, ранняя диагностика: монография / А.И. Пашов, Б.Б. Цхай, Ю.А. Дыхно. - Новосибирск: Наука, 2013. - 258 с.

18. Tatarchuk, T.F., Kalugina, L.V.

"On the question to treatment of endometrial hyperplastic processes." Reproductive endocrinology 2.4 (2012): 88-92. D01: 10.18370/2309-4117.2012.4.88-93

Татарчук, Т.Ф.

К вопросу о лечении гиперплазии эндометрия / Т.Ф. Татарчук,

Л.В. Калугина // Репродуктивная эндокринология. - 2012. - № 2

(4). - C. 88-92.

19. Tatarchuk, T.F., Kalugina, L.V.

"Endometrial polyps. Is preventive treatment necessary?"

Reproductive endocrinology 2.10 (2013): 69-75. D01:

10.18370/2309-4117.2013.10.69-75

Татарчук, Т.Ф.

Полипы эндометрия. Нужна ли противорецидивная терапия? /

Т.Ф. Татарчук, Л.В. Калугина // Репродуктивная эндокринология. 2013. - № 2(10). - C. 69-75.

20. Tatarchuk, T.F., Kovalenko, E.P., Filonenko, T.G., Kubyshkin, A.V. "Expression of steroid hormone receptors and levels of estrogen and progesterone in uterine washes of women with endometrial hyperplasia." Health of woman 6.62 (2011): 105-10.

Татарчук, Т.Ф.

Экспрессия рецепторов к стероидным гормонам и уровень эстрогенов и прогестерона в маточных смывах женщин с гиперплазиями эндометрия / Т.Ф. Татарчук, Е.П. Коваленко, Т.Г. Филоненко, А.В. Кубышкин // Здоровье женщины. - 2011. № 6 (62). - C. 105-110.

21. Tuchkina, I.A., Gilenko, Z.O., Kalashnik, N.V., Vygouskaja, L.A. "Clinical and hormonal characteristics and therapy of girls with endometrial hyperplasia on the background of anemia." International Medical Journal 3 (2014): 87-91.

Тучкина, И.А.

Клинико-гормональная характеристика и терапия девушек с гиперплазией эндометрия на фоне анемии / И.А. Тучкина, ж.О. Гиленко, Н.В. Калашник, Л.А. Выговская // Міжнародний медичний журнал. - 2014. - № 3. - С. 87-91.

22. Sheshukova, I.0., Makarov, I.0., Borovkova, E.I.

"Prognostic factors for the development of hyperplastic processes in the endometrium during perimenopause." Rossiyskiy vestnik akushera-ginekologa 11.4 (2011): 13-6.

Шешукова, И.0.

Прогностические факторы развития гиперпластических процессов в эндометрии в период перименопаузы / И.О. Шешукова, И.О. Макаров, Е.И. Боровкова // Российский вестник акушера-гинеколога. - 2011. - № 11(4) - - С. 13-16. 23. Annan, J., Aquilina, J., Ball, E.

"The management of endometrial polyps in the 21st century."The Obstetrician \& Gynaecologist 14 (2012): 33-8.

24. Lenci, M.A., Nascimento, V.A., Grandini, A.B., et al.

"Premalignant and malignant lesions in endometrial polyps in patients undergoing hysteroscopic polypectomy." Einstein (SaoPaulo)

12 (2014): $16-21$.

25. Morotti, M., Menada, M.V., Moioli, M.

"Frozen section pathology at time of hysterectomy accurately predicts endometrial cancer in patients with preoperative diagnosis of atypical endometrial hyperplasia." Gynecol Oncol 125.3 (2012): 536-40. 
MODERN TREATMENT OF ENDOMETRIAL LOCAL HYPERPLASTIC PROCESSES FROM POSITIONS OF THE PATHOGENIC APPROACH

V.0. Benyuk, MD, professor, head of the Obstetrics and Gynecology Department No. 3, Bogomolets National Medical University, Kyiv Y.V. Kravchenko, graduate student, Obstetrics and Gynecology Department No. 3, Bogomolets National Medical University, Kyiv

T.V. Kovaliuk, PhD, assistant professor, Obstetrics and Gynecology Department No. 3, Bogomolets National Medical University, Kyiv

S.V. Beniuk, PhD, assistant professor, Obstetrics and Gynecology Department No. 3, Bogomolets National Medical University, Kyiv

I.A. Usevych, PhD, assistant professor, Obstetrics and Gynecology Department No. 3, Bogomolets National Medical University, Kyiv

Purpose of research: to improve the treatment effectiveness of patients with endometrial local hyperplasia by use of endoscopic technologies and pathogenetical postoperative therapy. Materials and methods. 66 women whose treatment algorithm included 4 stages (hysteroscopic polyp ablation followed by the morphological study, hormonal therapy aimed at the endometrium suppression, hormonal status optimization and dispensary observation within 5 years) were the subject of the study. After complex examination and histological verification of endometrial polyposis diagnosis patients were divided into two groups: $A(n=34)$ with the immune corrective therapy and $B(n=32)$. Examination algorithm included the endometrial immune histochemical examination with its immune histochemical profile definition.

Study results. Histological screening of endometrium state resulted that 9 (26.5\%) patients in the A group had the chronic endometritis features. The corresponding index for the B group stood for 15 patients (46.9\%) that is $20.4 \%$ higher compared to the A group. Estrogen receptors expression with the background of progestogen treatment indicated the 1.2 times lowering for both groups. The viral and bacterial complex screening indicated the endometrial pathogenic contamination dramatic decrease. Study of tumor necrosis factor's level determined the straightforward tendency with the CD 138 index dynamics. In a year term the complete treatment effect in A group was observed among 29 patients (85.2\%), and the endometrial polyposis recurrence was observed among 5 (14.8\%) patients.

Conclusions. It is necessary to take into account the woman's age, joint genital and somatic pathology's presence and the immune histochemical profile of hyperplastic endometrial while determining the endometrial pathology differentiated treatment tactics. Additional immune corrective therapy with the antibacterial treatment determines the receptor phenotype restoration, normalization of tumor necrosis factor-a lever and increases the endometrial polyposis treatment effectiveness up to $22.7 \%$.

Keywords: intrauterine pathology, endometrial local hyperplasia, endometrial polyposis, uteroscopy, immune histochemical study, cytokines.

\section{СУЧАСНЕ ЛККУВАННЯ ЛОКАЛЬНИХ ГІПЕРПЛАСТИЧНИХ ПРОЦЕСІВ ЕНДОМЕТРІЯ З ПОЗИЦІї ПАТОГЕНЕТИЧНОГО ПІДХОДУ}

В.0. Бенюк, д. мед. н., професор, завідувач кафедрою акушерства та гінекології №3 нМУ ім. 0.0. Богомольця, м. Київ

Ю.В. Кравченко, аспірант кафедри акушерства та гінекології №3 нмУ ім. 0.0. Богомольця, м. Київ

Т.В. Ковалюк, к. мед. н, доцент кафедри акушерства та гінекології №3 НмУ ім. 0.0. Богомольця, м. Київ

С.В. Бенюк, к. мед. н, доцент кафедри акушерства та гінекології №3 нмУ ім. 0.0. Богомольця, м. Київ

І.А. Усевич, к. мед. Н, доцент кафедри акушерства та гінекології №3 НмУ ім. 0.0. Богомольця, м. Київ

Мета дослідження: підвищення ефективності лікування хворих з локальною гіперплазією ендометрія шляхом застосування ендоскопічних технологій та патогенетично обгрунтованої післяопераційної терапії.

Матеріали і методи. У дослідження включили 66 жінок, алгоритм лікування яких складався 3 етапів: гістероскопічне видалення поліпа і зміненого ендометрія з подальшим морфологічним дослідженням, гормональна терапія, спрямована на супресію ендометрія, оптимізація гормонального статусу, диспансерне спостереження протягом 5 років. Після комплексного обстеження і гістологічної верифікації діагнозу хворі з поліпозом ендометрія були розділені на дві групи: група A ( $n=34)$, яка додатково отримувала імунокоригуючу терапію, і група B ( $n=32)$. Алгоритм обстеження включав імуногістохімічне дослідження ендометрія з визначенням його імуногістохімічного профілю.

Результати дослідження. Гістологічний скринінг стану ендометрія показав, що у 9 (26,5\%) хворих групи А спостерігалися ознаки хронічного ендометриту. У групі В цей показник Склав 15 (46,9\%), що на 20,4\% більше, ніж у групі А. Рівень експресії естрогенових рецепторів на фоні лікування прогестинами показав зниження в 1,2 разу в обох групах. Проведення комплексного вірусно-бактеріального скринінгу показало різке зменшення кількості патогенів контамінації ендометрія. Дослідження рівня фактора некрозу пухлини в змивах 3 порожнини матки засвідчило односпрямовану тенденцію з динамікою показника СD 138. Повний ефект лікування в групі А визначено через рік у 29 (85,2\%) хворих, у 5 (14,8\%) жінок спостерігали рецидив поліпозу ендометрія.

Висновки. Визначаючи тактику диференційованого лікування патології ендометрія, необхідно враховувати вік жінки, наявність поєднаної генітальної і супутньої соматичної патології, дані імуногістохімічного профілю гіперплазованого ендометрія. Доповнення антибактеріального лікування імунокоригуючою терапією сприяє відновленню рецепторного фенотипу, нормалізації рівня фактору некрозу пухлин, збільшує на 22,7\% ефективність лікування локальної гіперплазії ендометрія (поліпів ендометрія).

Ключові слова: внутрішньоматкова патологія, локальна гіперплазія ендометрія, поліпоз ендометрія, гістероскопія, імуногістохімічне дослідження, цитокіни.

\section{СОВРЕМЕННОЕ ЛЕЧЕНИЕ ЛОКАЛЬНЫХ ГИПЕРПЛАСТИЧЕСКИХ ПРОЦЕССОВ ЭНДОМЕТРИЯ С ПОЗИЦИИ ПАТОГЕНЕТИЧЕСКОГО ПОДХОДА}

В.А. Бенюк, д. мед. н., профессор, заведующий кафедрой акушерства и гинекологии № 3 НМУ им. А.А. Богомольца, г. Киев

Ю.В. Кравченко, аспирант кафедры акушерства и гинекологии № 3 НмУ им. А.А. Богомольца, г. Киев

Т.В. Ковалюк, к. мед. Н., доцент кафедры акушерства и гинекологии № 3 НМУ им. А.А. Богомольца, г. Киев

С.В. Бенюк, К. мед. Н., доцент кафедры акушерства и гинекологии № 3 НмУ им. А.А. Богомольца, г. Киев

И.А. Усевич, к. мед. н., доцент кафедры акушерства и гинекологии № 3 НМУ им. А.А. Богомольца, г. Киев

Цель исследования: повышение эффективности лечения больных с локальной гиперплазией эндометрия путем применения эндоскопических технологий и патогенетически обоснованной послеоперационной терапии.

Материалы и методы. В исследование вошли 66 женщин, алгоритм лечения которых состоял из 4 этапов: гистероскопическое удаление полипа и измененного эндометрия с последующим морфологическим исследованием, гормональная терапия, направленная на супрессию эндометрия, оптимизация гормонального статуса, диспансерное наблюдение в течение 5 лет. После комплексного обследования и гистологической верификации диагноза больные с полипозом эндометрия были разделены на две группы: группа $\mathrm{A}$ ( $\mathrm{n}=34$ ), которая дополнительно получала иммунокорригирующую терапию, и группа B ( $n=32)$. Алгоритм обследования включал иммуногистохимическое исследование эндометрия с определением его иммуногистохимического профиля.

Результаты исследования. Гистологический скрининг состояния эндометрия показал, что у 9 (26,5\%) больных группы А наблюдались признаки хронического эндометрита. В группе В этот показатель составил 15 (46,9\%), что на 20,4\% больше, чем в группе А. Уровень экспрессии эстрогеновых рецепторов на фоне лечения прогестинами показал снижение в 1,2 раза в обеих группах. Проведение комплексного вирусно-бактериального скрининга выявило резкое уменьшение количества патогенов контаминации эндометрия. Исследование уровня фактора некроза опухоли в смывах из полости матки указало на однонаправленную тенденцию с динамикой показателя (D 138. Полный эффект лечения в группе А определен через год у 29 (85,2\%) больных, у 5 (14,8\%) женщин наблюдали рецидив полипоза эндометрия.

Выводы. Определяя тактику дифференцированного лечения патологии эндометрия, необходимо учитывать возраст женщины, наличие сочетанной генитальной и сопутствующей соматической патологии, данные иммуногистохимического профиля гиперплазированного эндометрия. Дополнение антибактериального лечения иммунокорригирующей терапией содействует восстановлению рецепторного фенотипа, нормализации уровня фактора некроза опухоли, увеличивает на 22,7\% эффективность лечения локальной гиперплазии эндометрия (полипов эндометрия).

Ключевые слова: внутриматочная патология, локальная гиперплазия эндометрия, полипоз эндометрия, гистероскопия, иммуногистохимическое исследование, цитокины. 